\title{
NOMENCLATURE
}

Edited by John McNeill \& Anthony E. Orchard

\section{The nomenclatural history of Fritillaria eduardii and the correct names of its varieties}

\author{
Willem A. Wietsma, ${ }^{1}$ Ronald G. van den Berg, ${ }^{2}$ Johan van Scheepen ${ }^{3}$ \& Jan J. Wieringa ${ }^{4}$ \\ 1 V.O.F. de Keizerskroon, Harlingerstraatweg 36, 8872 NB, Midlum, The Netherlands \\ 2 Biosystematics Group, Wageningen University, Droevendaalsesteeg 1, 6708 PB, Wageningen, The Netherlands \\ 3 Royal General Bulb Growers' Association (KAVB), Weeresteinstraat 10a, 2181 GA, Hillegom, The Netherlands \\ 4 Netherlands Centre for Biodiversity Naturalis (section NHN), Herbarium Vadense (WAG), Biosystematics Group, \\ Wageningen University, Droevendaalsesteeg 1, 6708 PB, Wageningen, The Netherlands \\ Author for correspondence: Willem Wietsma, info@keizerskroon.net
}

\begin{abstract}
Material of a new fritillary was mentioned in four publications by Eduard Regel in 1884, but he used different names for this material. In the first publication it was named Fritillaria eduardii, but in the following publications the material was described as two varieties of $F$. imperialis L., both odourless, one with purplish flowers and one with yellow or yellow-red flowers. Both colour varieties, but especially the latter, have been taken into cultivation. Morphological observations and crossing experiments have established that both varieties do not belong to F. imperialis and should be accommodated in F. eduardii. New names for these varieties are proposed, following E. Regel's intention as closely as possible.
\end{abstract}

Keywords crossing-experiments; Fritillaria; Liliaceae; nomenclature; Petilium

\section{- INTRODUCTION}

The genus Fritillaria L. (Liliaceae) consists of more than 100 species of geophytic perennials. The genus is distributed in the Northern Hemisphere: Europe (the majority in the Mediterranean region), Central Asia, China, Japan, and North America. The well-known species Fritillaria imperialis (crown imperial) is a member of $F$. sect. Petilium Endl., a group that was first considered as a separate genus (mentioned by Linnaeus, 1738: 119 and validated by Ludwig, 1757: 135) and later treated as a subgenus (Baker, 1874) or section (Bentham \& Hooker, 1883: 817-818).

Mathew (1996) lists four species in this group: F. chitralensis (hort.) B. Mathew, F. eduardii Regel, F. imperialis L., and F. raddeana Regel; Govaerts (2010) recognises only the last three species. Fritillaria sect. Petilium has a widespread distribution from SE Turkey, NE Iraq, Turkestan, Iran, Tajikistan, Uzbekistan, Baluchistan, Afghanistan, and western Himalayas as far east as the Chenab Valley (Turrill \& Sealy, 1980).

Eduard Regel published four papers in 1884 discussing a fritillary collected by his son Albert Regel. Regel (1884a) treated this species as "Fritillaria Eduardi A. Rgl.", but later he assigned it to F. imperialis (Regel, 1884b, c, d). In the first paper Regel only mentions big purple flowers ("grossen purpurfarbenen Blumen"), in the later papers two colour varieties were described, one with purplish flowers and one with yellow/yellow-red/orange flowers. The latter orange variety is found in cultivation (Clark \& Grey-Wilson, 2003) under the name $F$. eduardii (e.g., by the companies Dix, Export B.V. Heemstede, The Netherlands; PC Nijssen, Bijzondere Bol \& Knolgewassen, Heemstede,
The Netherlands; Augis Bulbs, Lithuania; Janus Ruksans, Bulb Nursery, Latvia). Although it is usually the orange colour variety that is offered, hybrids between the orange and purple varieties do occur. Both varieties are present in collections (Hortus Bulborum, Limmen, The Netherlands; V.O.F. de Keizerskroon, Midlum, The Netherlands). There is, however, some confusion about the nomenclature applied to this material.

In the present paper we aim to reconstruct the nomenclatural history of the name F. eduardii, and establish the correct author designation of this name and the correct names for its colour varieties.

\section{口 NOMENCLATURAL HISTORY}

The year 1884. - In 1878 and 1879 Albert Regel collected fritillaries in the Mountains of Darwas and Baldschuan, East Buchara (Bukhara), nowadays Tajikistan, and possibly in the adjacent mountains of Afghanistan, and introduced them into cultivation in St. Petersburg, Russia (Regel, 1884a; Turrill $\&$ Sealy, 1980). In 1884, four articles in which a new fritillary was discussed were published by his father Eduard Regel (Regel, 1884a, b, c, d).

In Regel (1884a), the March issue of Gartenflora, a newly discovered species is presented and formally described. The plant (a dry specimen; living bulbs had been brought home as well, but they had not yet flowered), was described as a close relative of crown imperial, Fritillaria imperialis, with a height of 1-2 feet [ca. 30-65 cm], a stem with many leaves, and large purple coloured flowers. Eduard Regel did not consider this 
new fritillary as a form of $F$. imperialis because of the absence of smell in both the bulbs and flowers and the shorter leafless neck. "Fritillaria Eduardi" had apparently been proposed by his son, but there is no formal publication by Albert Regel.

In a second article (Regel, 1884b), the June issue of Gartenflora, E. Regel mentioned this material again, but now designated it as a variant/deviating variety ("Abart") of crown imperial and introduced the name "Fritillaria imperialis inodora", i.e., F. imperialis var. inodora Regel. He distinguished the material on the sole character that the bulbs do not have the unpleasant odour of normal $F$. imperialis. In this case living plants were examined on the occasion of an "Internationale Gartenbau-Ausstellung" that took place in St. Petersburg in May 1884. Regel writes: "Eine schöne Abart dieser geruchlosen Form besitzt schöne dunkelpurpurne Blumen" [A beautiful variant of this odourless variant has beautiful dark purple flowers]. Apparently there were more odourless variants with different flower colours. The reason why the material was now assigned to $F$. imperialis was not given, and no reference was made to his earlier publication (Regel, 1884a).

In Regel (1884c), the September issue of Gartenflora, E. Regel wrote a series of "Originalabhandlungen" [original papers], the first of which is titled "A. Fritillaria imperialis L. var. inodora purpurea Rgl." In this paper he mentioned again that A. Regel collected many fritillary bulbs and that some of these flowered like the cultivated plant (F. imperialis) with yellowish or yellow-red flowers, but some with brownpurple flowers as the one illustrated in "Taf. [= Tafel] 1165", a colour plate with the legend: "Fritillaria imperialis L. var. inodora purpurea Rgl." (Fig. 1A). This brown-purple flowering fritillary had a shorter leafless neck compared to the cultivated $F$. imperialis and the flowers were initially (in bud stage) more upright. Regel drew attention to the horticultural value of these odourless forms from the Buchara province. No direct reference was made to his earlier publications.

The fourth article was published by E. Regel in Trudy Imperatorskago S.-Peterburgskago Botanicheskago Sada (= Acta Horti Petropolitani) (Regel, 1884d), most probably after the September issue of Gartenflora, because it referred to the previous article (Regel, 1884c). In this article, in a section entitled "Descriptiones et emendationes plantarum bucharicarum turkestanicarumque", a "16. Fritillaria imperialis $L$. (spec. 435) var. inodora" was treated, with odourless bulbs and two colour variants: 1. ("lus. a.") with saffronyellow, nodding flowers, and 2. ("lus. b.") with purple, erect or horizontal flowers. Three places of origin were mentioned in East Buchara (nowadays Tajikistan and possibly in the adjacent mountains in Afghanistan): the eastern slopes of the mountain Gasi-Mailik, eastern slopes of the mountain Boratag, and Chanate Darwas, close to Schikai at the river Pändsch. Unfortunately it was not mentioned which colour variant was found on which location, or whether these colour variants grew together. A note on page 654 explained that because the bulbs lacked the unpleasant smell, and the dry specimens of the purple-flowered form that he examined showed upright or horizontally spreading flowers and a short neck under the spiked tuft, it was believed to be a new species. But when he saw living plants flowering, E. Regel concluded that the purple form was just an odourless $F$. imperialis. However, the article was illustrated with a plate ("Tab. II", a black and white drawing) with the legend "Fritillaria Eduardi A. Rgl." (Fig. 1B). According to the explanation of Tab. II, on page 699, this should be considered a plate of Fritillaria imperialis L. var. inodora and the name F. Eduardi A. Rgl. should be deleted ("Nomen F. Eduardi A. Rgl. delendum est."). This plate clearly illustrated a plant different from that in Tafel 1165 in Regel (1884c). The flowers of the plant depicted in Tab. II are already open before the stem is elongated, while the plant in Tafel 1165 shows an elongated stem with flowers in bud.

As far as we know, no more articles concerning this fritillary were published by E. Regel.

Later sources. - In Gartenflora 34 (Anonymous, 1885), an unnamed author (presumably Berthold Stein, the editor) summarized Regel's (1884d) description of 96 new taxa from the Buchara expedition and expressed his hope that E. Regel himself would in due time discuss horticulturally interesting or botanically noteworthy material. About number 16., "Fritillaria imperialis L. var. inodora Rgl." Stein added that, since "der Name Eduardi A. Rgl." was the oldest, this name by priority ("lege prioritatis") must be changed to "Fr. imperialis L. var. Eduardi (A. Rgl.)".

In the Horti Krelageani Manuscript (Krelage, 1884) and several catalogues (Haage, 1885, 1886; Krelage, 1886) odourless bulbs were offered, usually under the entries "Fritillaria imperialis inodora" and "Fritillaria imperialis inodora purpurea". Details about flower colours are not always mentioned, but Haage (1886) refers to the lively dark purple-red flowers of "F. imperialis inodora purpurea".

Losina-Losinskaja (1935) treated $F$. eduardii as "F. Eduardii Rgl." (correcting the spelling of Regel (1884d) with one i), although she mistakenly used "F. Eduardi Rgl." in the key on page 232). She described the plant as possessing an inodorous bulb and erect or declined flowers (not nodding as in F. imperialis), with bright red perianth. In the note on page 244 Losina-Losinskaja stated: "The species $F$. Eduardii Rgl. was mentioned by A. Regel and was considered by him as synonymous with $F$. imperialis L. It differs, however, markedly in perianth colour and the lack of nodding flowers, and should therefore be separated."

In Flora Uzbekistanica, Vvedensky (1941: 473) treated $F$. eduardii as a species in the genus Petilium, as "P. Eduardi (A. Rgl.) Vved. comb. n." Three colours are mentioned: orangered, brick red, and purple-brown.

Turrill \& Sealy (1980), in their treatment of F. imperialis, mentioned that only two varieties of this species have been recorded from the wild: F. imperialis var. chitralensis and $F$. imperialis var. inodora. No wild-collected specimens of the latter variety were available for examination, but the authors summarized the history of the material collected by A. Regel and mentioned the two colour forms: "one with yellow or saffron-yellow flowers, all pendent, the other with purplish flowers erect or spreading to pendulous". They follow the nomenclature of Regel (1884c, d): "Albert Regel used the name $F$. eduardi for the plant in his account of his 
expedition (l.c. supra) and this name was printed on the plate which accompanied his father's article in Acta Horti Petropolitani 8: t. 2 (1884), though in the explanation of the plate on p. 699 E. Regel made it clear that this was a mistake and that the plant was to take the name $F$. imperialis var. inodora which he had given on p. 653. When the purplish-flowered plant was illustrated in the Gartenflora: t. 1165, E. Regel

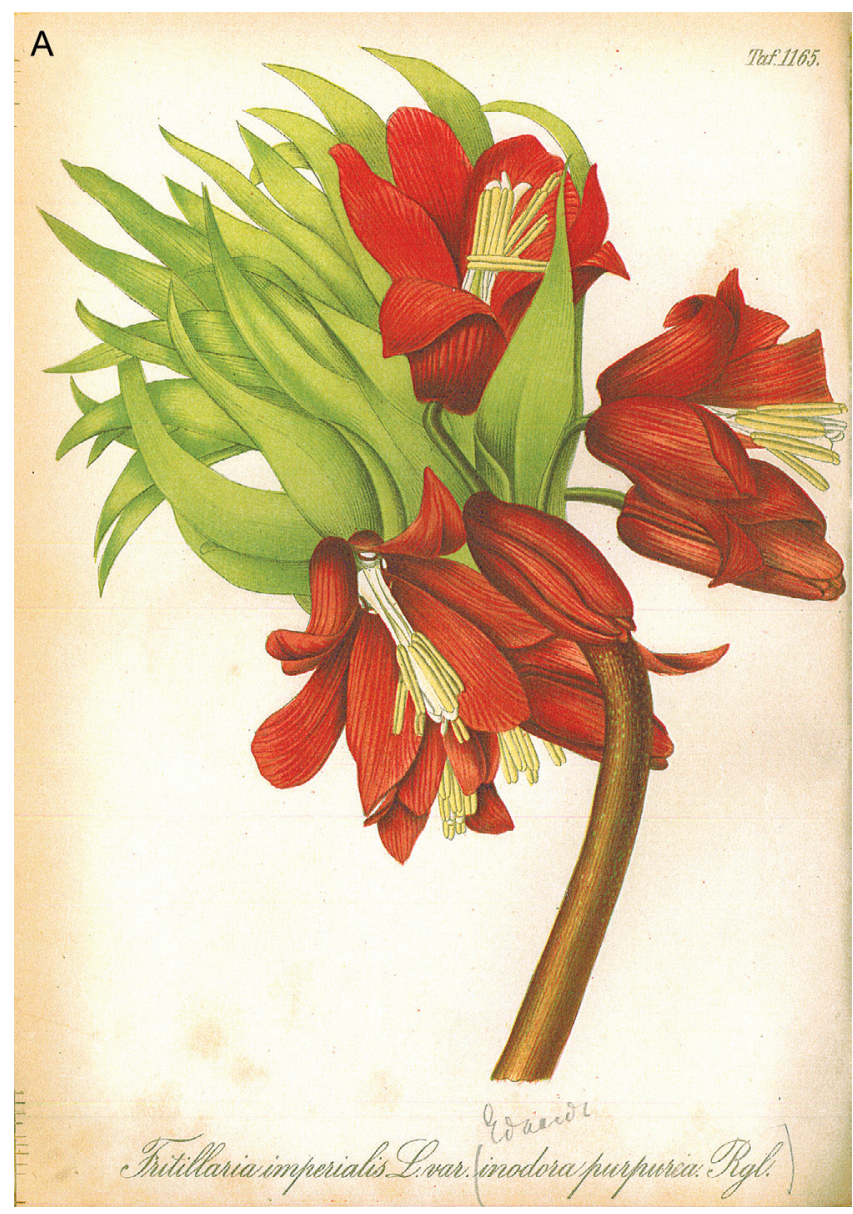

B

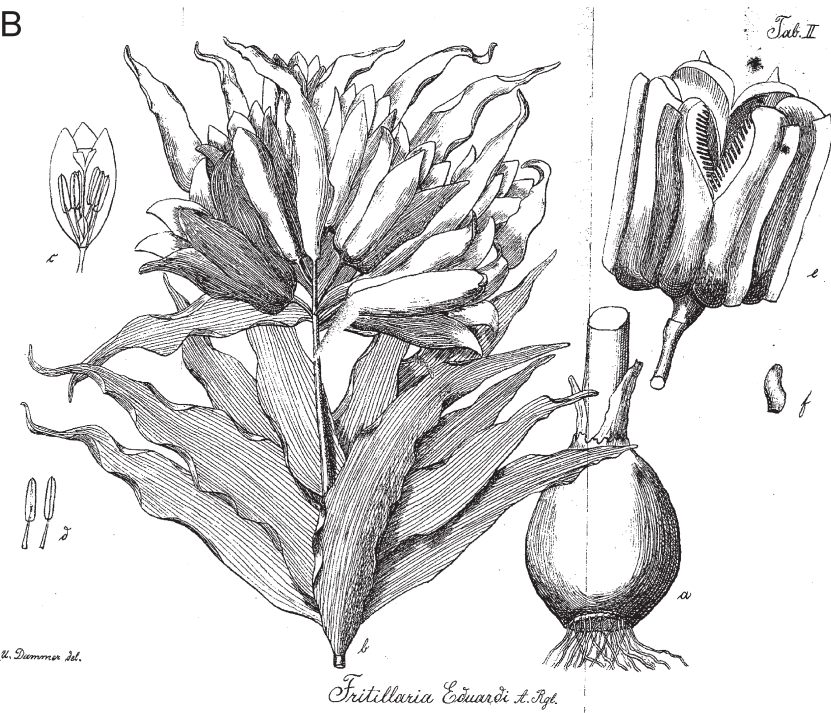

named it var. inodora purpurea, and under this name it came into cultivation in Britain."

More recently, the orange form is mentioned in a number of publications aimed at the garden enthusiasts (Mathew, 1996; Pratt \& Jefferson-Brown, 1997; Clark \& Grey-Wilson, 2003). In these publications the name $F$. eduardii is generally applied to this orange-flowered material. Pratt \& Jefferson-Brown
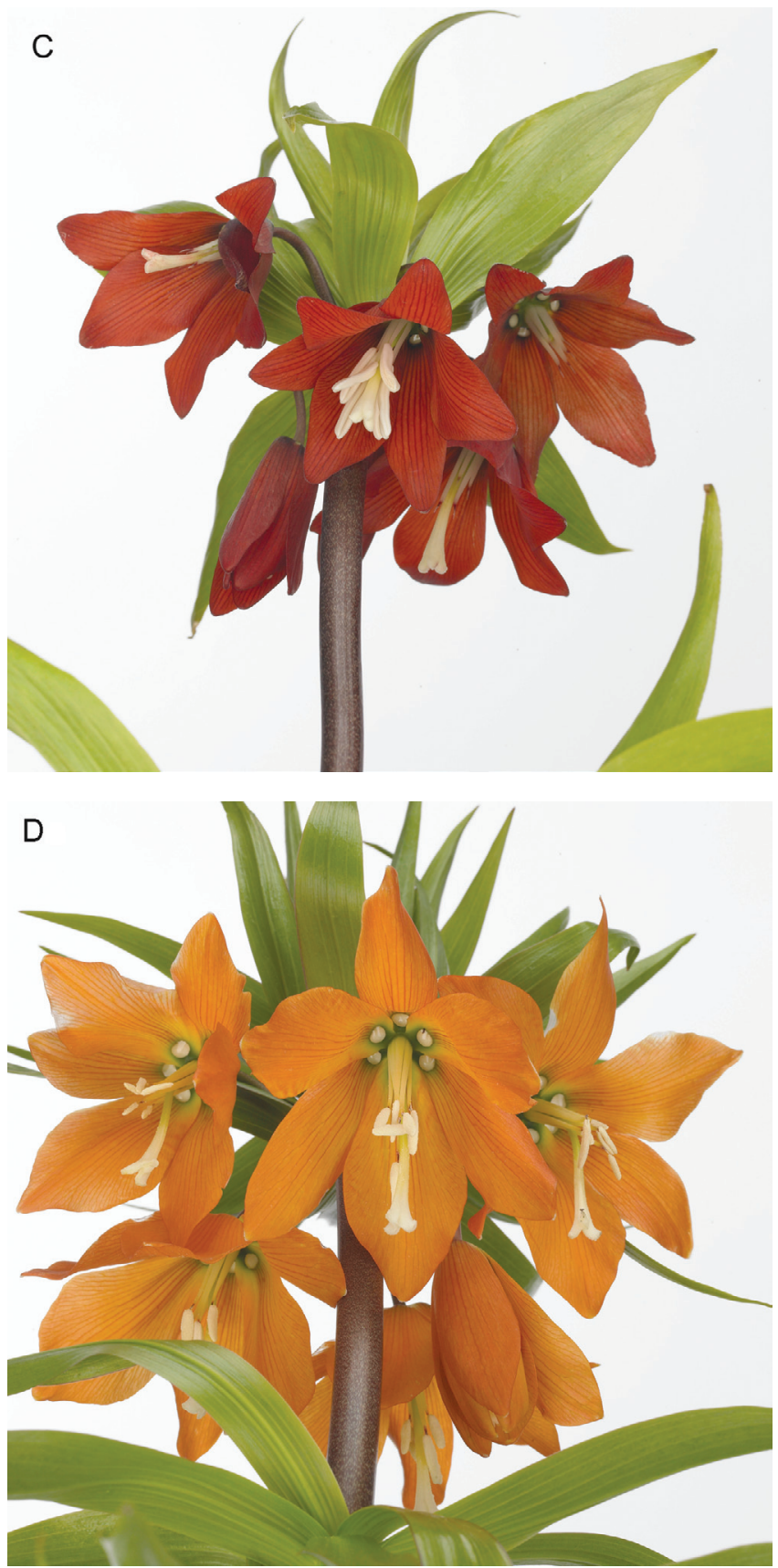

Fig. 1. A, Fritillaria eduardii var. eduardii (Regel, 1884c: Taf. 1165); note that the owner of this book, J.H. Krelage, corrected the name "inodora purpurea" to "Eduardi"; B, F. eduardii var. inodora Wietsma (Regel, 1884d: Tab. II); C, F. eduardii var. eduardii, collection Hortus Bulborum; D, F. eduardii var. inodora Wietsma, collection Hortus Bulborum. 
(1997) stated that $F$. eduardii Regel "has arisen as a hybrid between $F$. imperialis and $F$. raddeana."

In the Red Data Book of the Republic of Uzbekistan (Khabibulaev \& Pratov, 1998) "F. eduardii (Regel) Vved." is described as: "Flowers campanulate, brick-red or purple brown". This is the only modern source where the two colour forms are mentioned. Localities are mentioned, however no details on flower colour per locality are given.

In a field study in Kyrgyzstan by Milko (2005) several localities of "Petilium eduardii (Regel ex Lozinsk.) Vved." are mentioned, but here also no information on flower colours at the different locations is given. According to this source the clearest difference between "P. imperiale" and "P. eduardii", is that $P$. eduardii has odourless bulbs.

Finally, in the GRIN database (USDA, 2009) we find $F$. eduardii cited as $F$. eduardii Regel ex Losinsk., with a reference to Komarov (1935) and the comment: "invalid publication of this name by Regel verified from original literature". A date is given of this verification ("name verified 23/1/2002") but neither the authority nor arguments are mentioned (see further discussion below).

\section{DISCUSSION}

In order to establish the correct use of names for the fritillary discovered by A. Regel and the different colour variants within this species, we review the relevant literature below.

We do not follow the recognition of Petilium as a genus by Vvedensky (1941: 473) but accept the classification of this taxon at the sectional level within Fritillaria. We consider Fritillaria eduardii as the correct spelling of $F$. Eduardi, following Art. 60.11 of the current edition of the Code (McNeill \& al., 2006).

Since the publications of Eduard Regel (1884a, b, c, d) there has been confusion about the name Fritillaria eduardii. Regel (1884a) gives a clear description of the plant and the name is ascribed to his son, A. Regel. However, since there is no formal publication by A. Regel, this name must be ascribed to E. Regel as F. eduardii A. Regel ex Regel. The names published by E. Regel (1884b, c, d) include the same material but considered as belonging to the species $F$. imperialis. As we are convinced (in agreement with Losina-Losinskaja, 1935) that the material does not belong to $F$. imperialis, we consider $F$. eduardii A. Regel ex Regel the correct name and the later names as synonyms.

The GRIN database mentions Komarov (1935) as place of publication and indicates that the invalid publication of this name by Regel took place in Regel 1884d (mistakenly cited as 1883): "E. Regel, Trudy Imp. S.-Peterburgsk. Bot. Sada viii. 653. t. 2., 1883, pro syn." This is also the place of publication of $F$. eduardii listed in IPNI (www.ipni.org). However, we show that the original publication took place in Regel (1884a). We thus disagree with the comment in the GRIN database that the publication of the name $F$. eduardii by Regel was invalid and reject the author designation "Regel ex Losinsk."

We strongly disagree with the suggestion of Pratt \& Jefferson-Brown (1997) that $F$. eduardii should be considered as a hybrid between $F$. imperialis and $F$. raddeana. Normal crosses attempted at V.O.F. De Keizerskroon between F. imperialis and $F$. raddeana never resulted in F1-hybrids. Only when the cut-style technique (the style is cut with a razor blade just above the ovary and the pollen is put on the remaining style) was applied, were F1-hybrids obtained (Wietsma \& al., 1994). These F1-hybrids had much smaller flowers, comparable to $F$. raddeana, and no plants with orange or purple flowers were obtained.

As mentioned above, Losina-Losinskaja (1935) recognized that $F$. eduardii is different from $F$. imperialis. However, she erroneously attributed the reclassification of the material to $F$. imperialis to $\mathrm{A}$. Regel and ignored the validation of the name of A. Regel by his father, E. Regel. Furthermore, she applied the name to the bright red variant while E. Regel's original description was clearly intended to cover the purple-coloured variant (Regel, 1884a).

It is clear from the publications of E. Regel (1884b, c, d) that two colour variants are present: a yellow to yellow-red (orange) and a purple. These two variants differ in further characteristics. Studies on living plant material (Hortus Bulborum [hort.], V.O.F. de Keizerskroon [hort.]) show that the purple-flowered variant is taller (height $70-85 \mathrm{~cm}$ ), the flowers are pendulous and more closed (narrower), while the orange variant is shorter (height $55-70 \mathrm{~cm}$ ), with more erect/horizontal flowers when they open (but also pendulous at full flowering), and the flowers are more open (wider). Regel (1884c) makes it clear that $F$. imperialis var. inodora-purpurea Regel is a special form of what he previously described as F. imperialis var. inodora (an indirect reference to Regel, 1884b) and that it is distinguished by the brown-purple flowers. Although Regel frequently used the German word "Form" in reference to the new taxon and even mentions its "Abarten", his usage of "Form" should not be regarded as use of the rank forma, but should be translated as "variant" (as should "Abart", at least in this context). It is clear, however, that the purple-flowering material of the odourless plants is described using a new name, F. imperialis var. inodora-purpurea, while the rest of the odourless material is that already called $F$. imperialis var. inodora. Apparently there were more odourless variants with different flower colours, and F. imperialis var. inodora was not dark purple.

The statement of Anonymous (1885) that the name Fritillaria imperialis L. var. inodora Rgl. by priority ("lege prioritatis") should be changed to " $F$. imperialis L. var. Eduardi (A. Rgl.)" is incorrect since the priority rule only applies within a rank. Furthermore, the suggested author designation is incomplete.

Since 1884 material of $F$. eduardii has been distributed and traded in Europe under different names, but clearly an orange (yellow to yellow-red) and a purple variant were offered (Haage, 1885, 1886; Krelage, 1886). The orange variety is far more common, probably because the purple variety is much more difficult to propagate. After cutting the bulb with a knife, the orange variety makes adventitious bulbs, but the purple variety does not and can only be maintained by seeds. The application of the name $F$. eduardii to this orange material 
neglects the first application of this name by Regel (1884a) to purple-flowered material.

From the nomenclatural history described above we conclude that it is necessary to (1) refer material of both colour variants to the species $F$. eduardii since it is not $F$. imperialis, and to (2) recognize two varieties: Fritillaria eduardii var. eduardii for the purplish variant and Fritillaria eduardii var. inodora (Regel) Wietsma for the yellow to yellow-red (orange) variant. We treat the other names given by E. Regel as synonyms: $F$. imperialis var. inodora (1884b) and $F$. imperialis var. inodora-purpurea (1884c), or as a later isonym: F. imperialis var. inodora (1884d).

Apart from morphological reasons to establish these two varieties, there is pertinent information about their distinctness derived from crossing experiments. From 1987 onwards crossings between $F$. imperialis (cultivars) and both varieties of F. eduardii were attempted by V.O.F de Keizerskroon. Material was used from Hortus Bulborum, Limmen, the Netherlands and the collection of V.O.F. de Keizerskroon. These crosses were attempted outdoors for over more than 20 years but never resulted in F1-hybrids. Even when the cut-style technique was applied (Wietsma \& al., 1994), no F1-hybrids were obtained.

Crosses between $F$. eduardii var. eduardii and $F$. eduardii var. inodora and vice versa (normal pollination), result in intermediate F1-hybrids. The flower colour of the F1-hybrid is darker red compared to $F$. eduardii var. inodora, but not purple as in F. eduardii var. eduardii. These F1-hybrids, when crossed again with $F$. eduardii var. eduardii, result in intermediate flower colours, more dark red, although not purple as $F$. eduardii var. eduardii. Self-pollination of $F$. eduardii var. eduardii, results in plants with only purple flowers. Selfpollination of $F$. eduardii var. inodora results in plants with yellow to orange flowers.

\section{口 THE PROBLEM OF TYPIFICATION}

The most suitable type material would be the material that was studied by E. Regel in 1884, both for the species name $F$. eduardii and the heterotypic variety. This material could not be traced. However, according to Losina-Losinskaja (1935) the original material of $F$. eduardii was described from Tash-Mailik, Boratag, Pyandzh River, and a type should be present in St. Petersburg (LE). Unfortunately, no specimen was cited and we could not locate this type material. The published drawings (Tafel 1165 in Regel, 1884c, of F. eduardii var. eduardii and Tab. II in Regel, 1884d, of $F$. eduardii var. inodora (Fig. 1A, B) can be used to ascertain the intention of E. Regel in recognizing two varieties, but it is not clear if these drawings were present when E. Regel wrote his first paper (Regel, 1884a) and hence they cannot be regarded as "original material" as defined by the Code (Art. 9.10).

Since no original material is present we designate neotypes for Fritillaria eduardii and its varieties, using material (Fig. 1C, D) which is available in the Hortus Bulborum collection (Leijenhorst, 2004).
Fritillaria eduardii A. Regel ex Regel in Gartenflora 33: 69. 1884 EFritillaria imperialis var. eduardii (Regel) Anon. in Gartenflora 34: 124. $1885 \equiv$ Petilium eduardii (Regel) Vved. in Schreder \& Kudrjaschev, Fl. Uzbekist. 1: 473. 1941 - Neotype (designated here): Wietsma 1, Culta at Midlum, The Netherlands, 12. IV. 2011 (WAG).

\section{Fritillaria eduardii var. eduardii}

= Fritillaria imperialis var. inodora-purpurea Regel in Gartenflora 33: 257-258, Tafel 1165. 1884.

- "Fritillaria imperialis var. inodora Regel lus. b", in Trudy Imp. S.-Peterburgsk. Bot. Sada 8: 653. 1884.

Fritillaria eduardii var. inodora (Regel) Wietsma, comb. nov. $\equiv$ Fritillaria imperialis var. inodora Regel in Gartenflora 33: 167. 1884 - Neotype (designated here): Wietsma 2, Culta at Midlum, The Netherlands, 12. IV. 2011 (WAG).

- "Fritillaria imperialis var. inodora Regel lus. a", in Trudy Imp. S.-Peterburgsk. Bot. Sada 8: 653. 1884.

\section{口CONCLUDING REMARKS}

The results from the crossing experiments (with or without style) strongly indicated that $F$. eduardii var. eduardii and $F$. eduardii var. inodora do not belong to $F$. imperialis, but represent a distinct species. The crossing experiments between $F$. eduardii var. eduardii and F. eduardii var. inodora and vice versa, and backcrosses to both parents, always resulted in plants with intermediate flower colours. This suggests that both colour variants grow in separate locations. Unfortunately, no detailed information is available on the distribution areas. Fieldwork in the distribution area of this species (Middle Asia, Mountain areas in southwest and southeast Uzbekistan, Kyrgyzstan, Tajikistan, Afghanistan) would provide more information about this aspect.

To get more information on the genetic relationship of both colour variants, it will be interesting to apply molecular techniques, such as Amplified Fragment Length Polymorphism (AFLP). We plan to include all the members of the section $P e$ tilium in such a study to get insight in the relationships within the section.

\section{aCKNOWLEDGEMENTS}

We are indebted to V.O.F. de Keizerskroon (represented by Doede de Jong) for supplying plant material for this study.

\section{口 LITERATURE CITED}

Anonymous. 1885. IV. Literatur. Gartenflora 34: 124-128.

Baker, J.G. 1874. Revision of the genera and species of Tulipeae. J. Linn. Soc. Bot. 14: 211-310.

Bentham, G. \& Hooker, J.D. 1883. Genera plantarum, vol. 3, pt. 2.

Clark, T. \& Grey-Wilson C. 2003. Crown imperials. Plantsman 2: 33-47. 
Govaerts, R. 2010. World checklist of Liliaceae. Kew: The Board of Trustees of the Royal Botanic Gardens, Kew. http://www.kew.org/ wcsp/ (accessed 26 November 2010).

Haage, F.A. 1885. Verzeichniss über Blumenziebeln [catalogue], p. 7.

Haage, F.A. 1886. Verzeichniss über Blumenziebeln [catalogue], p. 4.

Khabibulaev, A.Sh. \& Pratov, U.P. 1998. Red Data Book of the Republic of Uzbekistan, vol. 1, Plants. Tashkent: Chinor ENK.

Komarov, V.L. 1935. Flora of the U.S.S.R. Leningrad: Izdatel'stvo Akademii Nauk SSSR.

Krelage, E.H. 1884. Horti Krelageani manuscript. Fritillaria imperialis inodora HK 269, Fritillaria imperialis inodora purpurea HK 270. KAVB Library, Hillegom, the Netherlands.

Krelage, E.H. 1886. Blumenzwiebeln, verschiedene Knollen- und Wurzelgewächse [catalogue]. 76 ${ }^{\mathrm{er}}$ Jahrgang, No. 383a, p. 25.

Leijenhorst, L. 2004. Hortus Bulborum: Treasury of historical bulbs. Wormerveer: Stichting Uitgeverij Noord-Holland.

Linnaeus, C. 1738. Hortus cliffortianus. Amsterdam.

Losina-Losinskaja, A.S. 1935. Genus 271. Fritillaria L. Pp. 232-246. in: Komarov, V.L. (ed.), Flora of the U.S.S.R., vol. 4. Leningrad: Izdatel'stvo Akademii Nauk SSSR.

Ludwig, C.G. 1757. Institutiones historico-physicae regni vegetabilis, ed. 2. Leipzig: apud Joh. Frid. Gleditschium.

Mathew, B. 1996. 288. Fritillaria chitralensis. Bot. Mag. 13: 27-32, t. 288.

McNeill, J., Barrie, F.R., Burdet, H.M., Demoulin, V., Hawksworth, D.L., Marhold, K., Nicolson, D.H., Prado, J., Silva, P.C., Skog, J.E., Wiersema, J.H. \& Turland, N.J. (eds.). 2006. International Code of Botanical Nomenclature (Vienna Code): Adopted by the Seventeenth International Botanical Congress Vienna, Austria, July 2005. Regnum Vegetabile 146. Ruggell: Gantner.
Milko, D.A. 2005. Petilium Edward (Petilium eduardii, Liliaceae) in Kyrgyzstan. Turczaninowia 8(2): 44-53. [in Russian]

Pratt, K. \& Jefferson-Brown, M. 1997. The gardeners' guide to growing fritillaries. Newton Abbot, Devon, U.K.: David \& Charles Publishers.

Regel, E. 1884a. Kurze Nachrichten über die letzten Sammlungen von A. Regel. Gartenflora 33: 68-73.

Regel, E. 1884b. Internationale Gartenbau-Ausstellung der Kaiserlichen Gartenbau-Gesellschaft in St. Petersburg vom 5./17.-17./29. Mai 1884. Gartenflora 33: 163-170.

Regel, E. 1884c. Fritillaria imperialis L. var. inodora purpurea Rgl. Gartenflora 33: 257-258, Tafel 1165.

Regel, E. 1884d. Descriptiones plantarum novarum et minus cognitarum, IX. Trudy Imp. S.-Peterburgsk. Bot. Sada [= Acta Horti Petropolitani] 8: 639-702, 21 figs.

Rix, E.M. 2001. Fritillaria: A revised classification. Edinburgh: The Fritillaria Group of the Alpine Garden Society, U.K.

Turrill, W.B. \& Sealy, J.R. 1980. Studies in the genus Fritillaria (Liliaceae) tabula 3849. Hooker's Icon. Pl. 39(1-2): 251-256.

USDA, ARS, National Genetic Resources Program (GRIN). 2009. Taxon: Fritillaria eduardii Regel ex Losinsk. http://www.ars-grin .gov/cgi-bin/npgs/html/taxon.pl?70865 (accessed 14 Dec. 2010).

Vvedensky, A.I. 1941. Petilium. P. 473 in: Schreder, R.R. \& Kudrjaschev, S.N. (eds.), Flora Uzbekistanica, vol. 1. Tashkent: Editio Academiae Scientiarum UzSSR.

Wietsma, W.A., de Jong, Y. \& Van Tuyl, J.M. 1994. Overcoming pre-fertilization barriers in interspecific crosses of Fritillaria imperialis and F. raddeana. Pl. Cell Incompat. Newslett. 26: 89-92. 